Acta Universitatis Nicolai Copernici • Pedagogika XXXI/2015

Nauki Humanistyczno-Społeczne • Zeszyt 426

DOI: http://dx.doi.org/10.12775/AUNC_PED.2015.005

\author{
Witold Wojdyło
}

Wydział Politologii i Stosunków Międzynarodowych

Uniwersytet Mikołaja Kopernika w Toruniu

\title{
TORUŃSKI OŚRODEK BADAŃ NAUKOWYCH W DZIEDZINIE HISTORII WYCHOWANIA \\ W LATACH 1991-2000 \\ REMINISCENCJE OSOBISTE
}

\begin{abstract}
T Tistoria wychowania jest dyscypliną naukową zajmującą się dzie- _jami teorii i praktyki edukacyjnej. W rozległym spektrum badawczym swym zasięgiem obejmuje badania historii szkolnictwa i instytucji oświatowo-wychowawczych, łącznie z historią ustroju, organizacji oświaty i wychowania wraz z historią doktryn, prądów i poglądów pedagogicznych. Różnorodność postaw badawczych doprowadziła w konsekwencji do ukształtowania się w Polsce dwóch głównych koncepcji badań w zakresie historii wychowania: historycznej i pedagogicznej. Pierwsza z nich postrzega historię wychowania jako naukę historyczną, której wiodącym zadaniem jest dociekanie i odtwarzanie zjawisk o zabarwieniu edukacyjnym. Z kolei druga, o wyraźnym podłożu pedagogicznym, włącza historię wychowania w obręb podstawowych działów (subdyscyplin) pedagogiki. W tej drugiej opcji, niezależ-
\end{abstract}


nie od poznawania genezy i funkcji społecznych zjawisk oświatowych, skupia się na ich wartościowaniu oraz ocenie ${ }^{1}$.

Historia wychowania jako dyscyplina naukowa ukształtowała się w końcu XIX i XX stulecia, zajmując się między innymi dziejami myśli i praktyki pedagogicznej. Jeden z jej najwybitniejszych przedstawicieli, a także polityk i dyplomata Stanisław Kot $^{2}$ stwierdzał, że: „Zadaniem historii wychowania jest badanie, jak w poszczególnych epokach, społeczeństwa organizowały u siebie wychowanie i dlaczego takie właśnie, a nie inne stosowały systemy pedagogiczne [...]. Historia wychowania wiąże się ściśle z całą historią kultury powszechnej i poszczególnych społeczeństw"3. Ten nieco dłuższy wywód z typologizacją historii wychowania w tle i dipolarnym podziałem badań jest o tyle istotny i ważny, iż w toruńskim środowisku badawczym przeplatały się i miały miejsce dwie koncepcje wychowawcze.

Badania naukowe w obrębie historii wychowania, prowadzone od 1945 roku i kontynuowane do dziś w Uniwersytecie Mikołaja Kopernika w Toruniu, mają nie tylko ważną konotację, lecz również wieloletnią tradycję. Związana jest ona między innymi z Katedrą Pedagogiki utworzoną w 1945 roku przez prof. dr. hab. Kazimierza Sośnickiego ${ }^{4}$, przemianowaną w 1952 roku w Katedrę Pedagogiki i Psychologii. Na-

${ }^{1}$ I. G. Michalscy, Historia wychowania. Hasło opracowane, w: Wielka Encyklopedia PWN, t. 11, Warszawa 2002, s. 340; Szerzej patrz: W. Szulakiewicz, Historia oświaty $i$ wychowania w Polsce 1918-1939. Studium historiograficzne, Toruń 2000 , s. 94-115.

${ }^{2}$ P. W. Rutkowski, Stanisław Kot (1885-1975). Biografia polityczna, Warszawa 2002; Szerzej patrz też: J. Dybiec, Stanisław Kot (1885-1975), Kraków 2000.

${ }^{3}$ S. Kot, Dzieje wychowania. Podręcznik dla zakładów kształcenia nauczycieli, Warszawa 1931, s. 11-12.

4 Pracownicy nauki i dydaktyki Uniwersytetu Mikołaja Kopernika 1945-2004. Materiały do biografii. Opracowali H. Duczkowska-Moraczewska, T. M. Gołębiewski, R. Karpiesiuk, B. Kierzkowska, E. Talarczyk, E. Wiśniewska. Koncepcja i redakcja S. Kalembka, Toruń 2006, s. 634 (Dalej cyt. Pracownicy nauki...). Sośnicki Kazimierz (1883-1976), pracownik naukowy i dydaktyczny UMK w latach 1945-1960. Prodziekan Wydziału Humanistycznego w latach 1945-1946; kierownik Katedry Pedagogiki i Psychologii 1945-1960. Wybitny teoretyk wychowania państwowego. Swoje koncepcje na ten temat przedstawił w pracy Podstawy wychowania państwowego, Warszawa-Lwów 1933. 
leży też zwrócić uwagę na fakt, że już w latach 40. ubiegłego wieku z toruńskim środowiskiem historyków wychowania związani byli tacy badacze, jak prof. dr hab. Stefan Wołoszyn ${ }^{5}$ oraz prof. dr hab. Bolesław Pleśniarski ${ }^{6}$ (późniejszy, wieloletni kierownik wspomnianej Katedry, dyrektor Instytutu Pedagogiki i Psychologii UMK w latach 1976-1978 i jednocześnie kierownik Zakładu Historii i Teorii Wychowania). W okresie nieco późniejszym do tego grona dołączył prof. dr hab. Jerzy Danielewicz ${ }^{7}$ i prof. dr hab. Teresa Wróblewska ${ }^{8}$. Z kolei w latach 1991-1996 pracami zmodernizowanego i zreorganizowanego pod względem profilu badań Zakładu Historii Wychowania i Myśli Społecznej Instytutu Pedagogiki UMK kierował prof. dr hab. Andrzej

5 Pracownicy nauki..., s. 758; Wołoszyn Stefan (1911-2004). Pracownik naukowy i dydaktyczny UMK w latach (1945-1951), adiunkt w Katedrze Pedagogiki. Znany przede wszystkim jako autor podręczników do historii wychowania: Dzieje wychowania i myśli pedagogicznej w zarysie, Warszawa 1964; Źródła do dziejów wychowania i myśli pedagogicznej (t. 13), Warszawa 1965, wyd. 2 zmienione i poszerzone, t. 1-4, Kielce 1995-1998. W 1998 roku wydał pracę pt. Nauki o wychowaniu w Polsce w XX wieku. Próba zarysu encyklopedycznego, Kielce 1998 oraz pracę pt. Pedagogiczne wędrówki przez wieki i zagadnienia, Warszawa 1996.

6 Pracownicy nauki..., s. 546-547. Pieśniarski Bolesław (1908-1987). Pracownik naukowy i dydaktyczny UMK w latach 1951-1978 zatrudniony w Katedrze Pedagogiki; młodszy asystent (1951), asystent (1951), st. asystent (1952), adiunkt (1954), zastępca profesora (1956), starszy wykładowca (1961), docent etatowy (1968), profesor nadzwyczajny (1978); dyrektor Instytutu Pedagogiki i Psychologii, kierownik Katedry Pedagogiki (1969-1976), kierownik Zakładu Historii i Teorii Wychowania (1976-1979). Autor takich opracowań, jak: Poglądy Wielkopolan na sprawy wychowawcze i oświatowe $w$ świetle prasy Wielkiego Księstwa Poznańskiego 1815-1847; Wychowanie w Gwardii i Armii Ludowej.

7 Pracownicy nauki..., s. 162. Danielewicz Jerzy Władysław (1921-1997). Pracownik naukowy i dydaktyczny UMK w Latach 1971-1991. Dyrektor Instytutu Pedagogiki i Psychologii (1984-1987), kierownik Zakładu Historii Oświaty i Wychowania (1984-1991). Zainteresowania naukowe koncentrowały się w kręgu Historii Polski i Powszechnej XIX i XX wieku, historii oświaty.

8 Pracownicy nauki..., s. 764. Wróblewska Teresa Barbara (1936). Pracownik naukowy i dydaktyczny UMK w latach 1975-1989, adiunkt w Zakładzie Historii Oświaty Wychowania. Autorka takich prac, jak: Działalność kulturalno-oświatowa polskich organizacji na Pomorzu w latach 1871-1914; Uniwersytet Rzeszy jako model hitlerowskiej uczelni wyższej; Dzieje nauki i oświaty w Polsce w latach II Rzeczypospolitej na Pomorzu w okresie zaborów. 
Wojtas9, obok którego niewielki zespół badawczy tworzyli: mgr Lucjan Broniewicz, dr Adam Marszałek, dr Michał Strzelecki i dr Witold Wojdyło $^{10}$.

W tle tych uwarunkowań determinowanych także kwalifikacjami merytorycznymi pracowników Zakładu (politolodzy - Andrzej Wojtas, Adam Marszałek, oraz historycy dziejów najnowszych - Lucjan Broniewicz, Michał Strzelecki, Witold Wojdyło) najskuteczniejszym sposobem realizacji zadań badawczych całego zespołu było zajęcie

9 Pracownicy nauki..., s. 751; J. Waskan, Pomiędzy nauka a praca dla uczelni, w: Pomiędzy kontynuacją a zmianą. Studia z myśli politycznej. W darze profesorowi Andrzejowi Wojtasowi $w$ siedemdziesiąta rocznicę urodzin, pod red. J. Waskana, Bydgoszcz 2012, s. 15-16; Wojtas Andrzej (1942) był pracownikiem naukowo-dydaktycznym UMK w latach 1984-1996. Prodziekan Wydziału Humanistycznego w latach 1986-1987, dziekan Wydziału Humanistycznego w latach 1987-1990, kierownik Zakładu Historii Wychowania i Myśli Społecznej w latach 1991-1996.

${ }_{10}$ Pracownicy nauki..., s. 114. Broniewicz Lucjan (1961-2010). Pracownik naukowy i dydaktyczny UMK w latach 1987-1992. Asystent w Zakładzie Historii Wychowania i Myśli Społecznej Instytutu Pedagogiki UMK początkowo u prof. dr. hab. Jerzego Danielewicza, a następnie u prof. dr. hab. Andrzeja Wojtasa. Po rozstaniu z UMK długoletni dyrektor planetarium. * Pracownicy nauki..., s. 449. Marszałek Adam (1952). Pracownik naukowy i dydaktyczny UMK w latach 1976-1994. Adiunkt w Zakładzie Historii Wychowania i Myśli Społecznej w latach 1991-1994. Po rozstaniu UMK założył działające do tej pory znane wydawnictwo „Adam Marszałek”. * Pracownicy..., s. 650. Strzelecki Michał (1963). Pracownik naukowy i dydaktyczny UMK w latach 1987-1997 oraz ponownie od 2010 roku. Adiunkt w Zakładzie Historii Wychowania i Myśli Społecznej w latach 1991-1997. Obecnie dr hab. prof. UMK, prodziekan Wydziału Politologii i Studiów Międzynarodowych.

* Pracownicy..., s. 750; Z. Karpus, G. Radomski, M. Strzelecki, O profesorze Witoldzie Wojdyle - człowieku, uczonym i mistrzu stów kilka, w: W kręgu historii, politologii i edukacji. Studia i szkice dedykowane profesorowi Witoldowi Wojdyle, pod red. Z. Karpusa, G. Radomskiego, M. Strzeleckiego, Toruń 2012, s. 17-22; Witold Wojdyło (1947). Pracownik naukowy i dydaktyczny UMK od 1985 roku. Adiunkt, następnie dr hab., profesor, profesor zwyczajny. W latach 1991-1999 adiunkt w Zakładzie Historii Wychowania i Myśli Społecznej, wicedyrektor Instytutu Pedagogiki UMK w latach 1993-1995, prodziekan i dziekan Wydziału Humanistycznego UMK 1996-2008, następnie prorektor ds. studenckich 2008-2012, obecnie kierownik Katedry Myśli Politycznej na Wydziale Politologii i Studiów Międzynarodowych UMK. 
się ideą wychowania społecznego w formacjach ideowo-politycznych w Drugiej Rzeczypospolitej, okresie okupacji hitlerowskiej i sowieckiej, po zakończeniu drugiej wojny światowej. Wychowanie społeczne traktowano bowiem jako długotrwałe, świadome i celowe i wielopłaszczyznowe działanie na rzecz rozwijania w jednostkach systemu wartości i norm pogłębiania poziomu identyfikacji z określoną wspólnotą, upowszechniania pożądanych oraz uwzględniających istniejące realia wzorców aktywności w przestrzeni publicznej, jak również ich przygotowanie do wypełniania określonych ról.

W zbliżony sposób istotę wychowania społecznego charakteryzowano już w okresie międzywojennym. Za symptomatyczne należy uznać w tym względzie ustalenia socjologa wychowania Floriana Znanieckiego stwierdzającego jednoznacznie, iż spoczywające na nim [tzn. wychowaniu społecznym - przyp. W. W.] zadanie to nade wszystko: „[...] dostarczenie grupom społecznym członków, przygotowanych do czynnego w nich udziału; grupy społeczne narzucają więc działalności wychowawczej zadanie, uzależnione od własnych swych potrzeb, oraz organizują i kontrolują wpływy wychowawcze, którym przyszli ich członkowie podlegają"11. Podobnie do omawianej kwestii odnosił się Józef Mirski, który nawiązując do ustaleń znanego niemieckiego socjologa i pedagoga Fryderyka Wilhelma Foerstera, stwierdzał, iż jest ono kształtowaniem jednostek w duchu przynależności do danej zbiorowości, a także rozwijaniem umiejętności współdziałania z nią oraz podporządkowywania się jej dążeniom i celom ${ }^{12}$. Istotnym więc punktem odniesienia dla tworzących go wszelkiego rodzaju oddziaływań są bowiem zawsze zdefiniowane ściśle ideologie, a także interesy określonych grup i struktur społecznych. Przy tym założeniu może ono przyjmować formy zróżnicowane, między innymi w postaci wychowania narodowego, państwowego, klasowego.

Przy tym założeniu jednym z głównych postulatów badawczych wszystkich pracowników Zakładu Historii Wychowania i Myśli Spo-

11 F. Znaniecki, Socjologia wychowania, t. II, Warszawa-Lwów 1930, s. 1.

12 J. Mirski, Współdziałanie młodzieży w pracy wychowawczej szkoły, Lwów-Warszawa [bdw], s. 15; patrz też: M. Zimnowicz, Problemy wychowawcze wspótczesnego, wyd. IV, Warszawa 1931. 
łecznej stało się odtwarzanie projekcji wychowania społecznego formułowanego i upowszechnianego w przestrzeni polskiej myśli politycznej ${ }^{13}$ Drugiej Rzeczypospolitej, okresu okupacji niemieckiej i sowieckiej, reżimu totalitarnego po zakończeniu drugiej wojny światowej, w trakcie transformacji ustrojowej po 1989 roku. Realizacja powyższego przedsięwzięcia w naturalny sposób rodziła także potrzebę uwypuklenia czynników determinujących zainteresowanie jej kreatorów wspomnianą problematyką badawczą, zaprezentowania sposobów interpretowania celów wychowania społecznego, a także postulowanych form ich urzeczywistniania oraz analizy różnic i zależności mających miejsce między różnymi formacjami ideowymi.

Scharakteryzowany powyżej profil zainteresowań badawczych pracowników Zakładu Historii Wychowania i Myśli Społecznej określony został w latach 1992-1994 w trakcie realizacji projektu badawczego w ramach grantu badawczego Komitetu Badań Naukowych „Wychowanie społeczne w koncepcjach politycznych i społecznych w Drugiej Rzeczypospolitej", którego kierownikiem i głównym koordynatorem był prof. dr hab. Andrzej Wojtas. Efektem finalnym prowadzonych wówczas badań była praca zbiorowa pt. Polityka a wychowanie. Szkice z historii wychowania społecznego II Rzeczypospolitej pod redakcją A. Wojtasa, Toruń 2004. W publikacji tej znalazły się między innymi artykuły: 1 . A. Wojtas, Polityka a wychowanie; tenże; Nurt etyczny wychowania społecznego w Polsce; 2. M. Strzelecki, Wychowanie w myśli społeczno-politycznej ruchu ludowego w Drugiej Rzeczypospolitej; 3. W. Wojdyło, Wychowawcze aspekty myśli politycznej obozu demokratyczno-narodowego 1918-1928. Natomiast w badaniach dalszych skoncentrowano się przede wszystkim na relacjach między założeniami ideowymi i działalnością polskich ugrupowań i stronnictw politycznych XX wieku a formułowanymi przezeń koncepcjami oświa-

13 Znacznie szerzej o różnorodnych wykładniach tego pojęcia patrz: W. Paruch, Myśl polityczna - refleksje metodologiczne o pojęciu, „Annales Universitatis Mariae Curie-Skłodowska", Sectio k. Politologia, vol. VI: 1999, Państwo-ludowcy-myśl polityczna, pod red. Z. J. Pietrasia, A. Wójcik, W. Parucha, s. 27-39; tenże, Między wyobrażeniami a działaniami. Wybrane aspekty przedmiotowe badań politologicznych nad myśla polityczną, "Polityka i Społeczeństwo” 2004, nr 1, s. 9-38. 
towymi i wychowawczymi, traktując tym samym wychowanie jako istotny element polityki oraz składnik transformacji społecznych. Ranga wspomnianej problematyki wynikała z faktu, iż wszystkie polskie ugrupowania polityczne dążyły do uzyskania wpływu na postępowanie i zachowanie jednostek, a w konsekwencji do aktywizacji społeczeństwa.

Począwszy od 1996 roku, po odejściu prof. dr. hab. Andrzeja Wojtasa do innego ośrodka naukowego (Wyższa Szkoła Pedagogiczna w Bydgoszczy - obecnie Uniwersytet Kazimierza Wielkiego), funkcję kierownika Zakładu, którego skład personalny ustalił się następująco: dr Michał Strzelecki, mgr Jarosław Góralski ${ }^{14}$, mgr Katarzyna Kalinowska ${ }^{15}$, pełnił do 2000 roku prof. dr hab. Witold Wojdyło. Prace badawcze Zakładu koncentrowały się wówczas w obrębie następujących zagadnień: 1. Witold Wojdyło - analiza dziejów idei społeczno-wychowawczych w Drugiej Rzeczypospolitej; procesy kształtowania świadomości narodowej i politycznej społeczeństwa polskiego XIX i pierwszej połowy XX wieku; badanie wzajemnych relacji pomiędzy wychowaniem a polityką, ze szczególnym uwzględnieniem koncepcji wychowania narodowego; 2. Michał Strzelecki - rola wychowania społecznego; koncepcje kształtowania społeczeństwa obywatelskiego w myśli politycznej ruchu ludowego; działalność legalnych środowisk opozycyjnych po II wojnie światowej; projekcje wychowania społecznego w polskiej myśli politycznej lat 1918-1939; 3. Jarosław Góralski - działalność oświatowo-wychowawcza Polskiej Macierzy Szkolnej; 4. Katarzyna Kalinowska - projekcje społeczno-polityczne i oświatowo-wychowawcze ojca Jacka Woronieckiego.

14 Pracownicy nauki..., s. 235. Góralski Jarosław (1970). Pracownik naukowy i dydaktyczny UMK w latach 1996-2000. Asystent w Zakładzie Historii Wychowania i Myśli Społecznej Instytutu Pedagogiki UMK u prof. dr. hab. W. Wojdyły.

15 Pracownicy nauki..., s. 319. Kalinowska Katarzyna (1973-2009). Pracownik naukowy i dydaktyczny UMK w latach 1997-2009. Asystent w zakładzie Historii Wychowania i Myśli Społecznej u prof. dr. hab. W. Wojdyły w latach 1997-2000, następnie adiunkt w Zakładzie Myśli Politycznej w katedrze Politologii UMK. Szerzej patrz: W kręgu idei. Państwo-edukacja-religia. Księga pamiątkowa ofiarowana dr Katarzynie Kalinowskiej, pod red. W. Wojdyły, G. Radomskiego, M. Zamojskiej, D. Góry-Szopińskiego, Toruń 2011. 
Badanie wzajemnych relacji pomiędzy polityką a wychowaniem stanowiły również przedmiot rozważań uczestników interdyscyplinarnej konferencji naukowej: Wychowanie a polityka. Tradycje i wspótczesność, zorganizowanej przez pracowników Zakładu Historii Wychowania i Myśli Społecznej Instytutu pedagogiki UMK 7-8 listopada 1996 roku, w której obok historyków wychowania udział wzięli również historycy myśli politycznej, filozofowie, pedagogowie, socjolodzy oraz historycy literatury reprezentujący różne środowiska akademickie, a także historycy wychowania z Uniwersytetu w Oldenburgu, z którym toruńscy badacze utrzymują do dziś stałe kontakty naukowe. Zamierzeniem organizatorów konferencji było nadanie jej charakteru cyklicznego i tym samym wpisanie na stałe do kalendarza spotkań przedstawicieli dyscyplin naukowych podejmujących wspomnianą problematykę. Planowane przedsięwzięcie zostało zrealizowane na przestrzeni lat 1996-2008; zdołano zorganizować sześć cyklicznych konferencji tego typu, których zmaterializowanym wytworem stało się sześć zbiorowych publikacji: Polityka a wychowanie. Szkice z historii wychowania społecznego II Rzeczypospolitej pod redakcja A. Wojtasa, Toruń 2004; Wychowanie a polityka. Tradycje i wspótczesność pod redakcją W. Wojdyły i M. Strzeleckiego, Toruń 1997; Wychowanie a polityka. Między wychowaniem narodowym a państwowym pod redakcja W. Wojdyty, Torun 1999; Wychowanie a polityka. Mity i stereotypy $w$ polskiej myśli społecznej XX wieku pod redakcją W. Wojdyły, Toruń 2000; Wychowanie a polityka. Cele polityczne jako czynnik determinujacy oddziaływanie wychowawcze pod redakcja G. Radomskiego i K. Kalinowskiej, Toruń 2004; Wychowanie a polityka. Kultura polityczna a kształtowanie tożsamości społeczeństwa polskiego pod redakcją K. Kalinowskiej, Toruń 2008. W trakcie wspomnianych konferencji nawiązano bezpośrednie kontakty naukowe z profesorami: Dorotą Żołądź-Strzelczyk (UAM Poznań); Danutą Koźmian (Uniwersytet Szczeciński); Michałem Śliwą (Uniwersytet Pedagogiczny w Krakowie); Wiesławem Jamrożkiem (UAM Poznań); Krzysztofem Jakubiakiem (Uniwersytet Kazimierza Wielkiego w Bydgoszczy); Romanem Tomaszewskim (Wyższa Szkoła Pedagogiczna w Słupsku); Stefanią Walasek (Uniwersytet Wrocławski); Władysławą Szulakiewicz (Wyższa Szkoła Pedagogiczna w Rzeszowie); Wiesławem Theissem (Uni- 
wersytet Warszawski); Zbigniewem Kwiecińskim (UAM Poznań, UMK Toruń); Lechem Mokrzeckim (Uniwersytet Gdański); Juliuszem Judziłłem (Wyższa Szkoła Pedagogiczna w Bydgoszczy); Romualdem Turkowskim (Uniwersytet Warszawski); Eugeniuszem Ponczkiem (Uniwersytet Łódzki); Jarosławem Macałą (Uniwersytet w Zielonej Górze); Tomaszem Sikorskim (Uniwersytet Szczeciński); Krzysztofem Kawalcem (Uniwersytet Wrocławski); Andrzejem Chodubskim (Uniwersytet Gdański); Tadeuszem Kisielewskim (Uniwersytet Kazimierza Wielkiego w Bydgoszczy); Janem Waskanem (Uniwersytet Kazimierza Wielkiego w Bydgoszczy). W organizowanych przez Zakład Historii Wychowania i Myśli Społecznej konferencjach uczestniczyli także pracownicy naukowi UMK, w pierwszej kolejności z Instytutu Pedagogiki, m.in. profesorowie: Aleksander Nalaskowski, Ryszard Borowicz, Eugenia Anna Wesołowska, Marian Bybluk, Jerzy Bagrowicz, Józef Półturzycki, Bronisław Siemieniecki; z Instytutu Historii i Archiwistyki: Waldemar Rezmer, dr Małgorzata Strzelecka; z Instytutu Filozofii profesorowie: Ryszard Jadczak i Włodzimierz Tyburski; z Instytutu Socjologii profesorowie: Roman Bäcker i Marek Jeziński. Warto też odnotować stałą współpracę z Zakładem dr. Grzegorza Radomskiego.

Charakteryzując działalność naukową Zakładu Historii Wychowania i Myśli Społecznej, należy również podkreślić jego kontakty naukowe z Instytutem Historii i Archiwistyki, Instytutem Socjologii, Instytutem Filozofii oraz Pomorskim Archiwum Armii Krajowej, którego animatorem i współzałożycielką była legendarna „cichociemna”, generał brygady WP prof. dr hab. Elżbieta Zawacka ${ }^{16}$. Na uwagę zasługuje też niewątpliwie fakt podjęcia bezpośredniej współpracy z Wydawnictwem Adam Marszałek, wydawcą ogólnopolskiego interdyscyplinarnego kwartalnika „Kultura i Edukacja”, na łamach którego publikowano wiele artykułów z zakresu historii wychowania i myśli społecznej przedstawicieli różnych krajowych ośrodków naukowych.

Jak już wspomniano powyżej działalność dydaktyczna Zakładu Historii Wychowania i Myśli Społecznej związana była integralnie z funkcjonowaniem Instytutu Pedagogiki UMK i istniejącymi w nim

16 Szerzej patrz m.in.: Elżbieta Zawacka 1909-2009, pod red. A. Frąckowiak, R. Góralskiej, J. Półturzyckiego, H. Solarczyk-Szwec, W. Wojdyły, Radom 2009. 
kierunkami studiów. W konsekwencji pracownicy Zakładu prowadzili zajęcia z przedmiotu historia wychowania na pięcioletnich, stacjonarnych studiach magisterskich (30 godzin wykładów, 60 godzin ćwiczeń, II rok), trzyletnich, stacjonarnych studiach zawodowych (I rok, 15 godzin wykładów), a także pięcioletnich i trzyletnich (dla absolwentów studiów nauczycielskich), niestacjonarnych studiach magisterskich (I rok, 20 godzin wykładów, 20 godzin ćwiczeń). W Zakładzie prowadzono także seminaria magisterskie, których uczestnicy przygotowywali pod kierunkiem naukowym pracowników Zakładu prace poświęcone różnorodnym aspektom polskiej myśli społecznej i edukacyjnej oraz funkcjonowaniu regionalnych placówek edukacyjno-wychowawczych w XX wieku. W okresie prawie dziesięcioletniej działalności Zakładu Historii Wychowania i Myśli Społecznej przygotowano ponad 300 prac magisterskich. Warto też odnotować fakt, iż w latach 1995-2000 prowadzono w Zakładzie w trybie niestacjonarnym seminarium doktoranckie. Zmaterializowanym efektem tych starań była publiczna obrona trzech prac doktorskich, sfinalizowanych nieco później, bo w latach 1999-2005, a w efekcie publikacja trzech samodzielnych monografii: 1. Grzegorz Radomski, Narodowa Demokracja wobec problematyki mniejszości narodowych $w$ Drugiej Rzeczypospolitej $w$ latach 1918-1926, Toruń 2006; 2. Katarzyna Kalinowska, Jacek Woroniecki o społeczeństwie i państwie, Lublin 2005; 3. Małgorzata Strzelecka, „Tygodnik Powszechny” wobec ideologizacji oświaty $i$ wychowania $w$ latach 1945-1989, Torun 2007. Natomiast w trybie stacjonarnym, w toku studiów doktoranckich prowadzonych w Instytucie Pedagogiki UMK, pracę doktorską pt. Działalność edukacyjna Polskiej Macierzy Szkolnej 1918-1939 przygotowała i obroniła w 2005 roku Karina Rusinek-Kotulska.

Na zakończenie, w formie ciekawostki, chciałbym wspomnieć o infrastrukturze materialnej Zakładu Historii Wychowania i Myśli Społecznej. Baza lokalowa Zakładu była zawsze niezwykle skromna, początkowo w jednym pomieszczeniu (pokój 111) w Instytucie Pedagogiki UMK przy ulicy Gagarina 5, a począwszy od 2005 roku w pokoju 139 przy ulicy Asnyka 2a, na I piętrze Instytutu Pedagogiki. W tej części budynku, w wydzielonym skrzydle, Zakład koegzystował bezpośrednio z Zakładem Dydaktyki: prof. dr hab. Józef Półturzycki (kie- 
rownik), dr Bolesława Jaworska, dr Renata Góralska; Zakładem Edukacji Ustawicznej i Pedagogiki Porównawczej: prof. dr hab. Eugenia Anna Wesołowska (kierownik), dr Alina Matlakiewicz, dr Hanna Solarczyk-Szwec, mgr Dariusz Jach; Zakładem Edukacji Chrześcijańskiej: ks. prof. dr hab. Jerzy Bagrowicz (kierownik), ks. dr Czesław Kustra; Zakładem Podstaw Pedagogiki: prof. dr hab. Roman Schulz (kierownik), dr hab. Krzysztof Rubacha, dr Beata Przyborowska; Zakładem Pedagogiki Opiekuńczo-Wychowawczej: prof. dr hab. Marian Bybluk (kierownik), dr hab. Henryk Depta, dr Piotr Petrykowski, dr Ireneusz Pyrzyk, dr Anna Więcławska; Zakładem Technologii Kształcenia: prof. dr hab. Bronisław Siemieniecki (kierownik), dr Wojciech Lewandowski, dr Aleksandra Skarbińska, dr Kazimierz Wieczorkowski, mgr Joanna Buczyńska.

Reasumując, należy więc podkreślić, iż głównym celem działalności naukowej niewielkiego grona pracowników Zakładu Historii Wychowania i Myśli Społecznej Instytutu Pedagogiki UMK w latach 1991-2000 było uczynienie z Torunia w miarę ówczesnych możliwości istotnego ośrodka w zakresie badań nad historią wychowania XX stulecia, a zwłaszcza w kontekście relacji między polityką a szeroko rozumianą problematyką oświatowo-wychowawczą.

Należy też odnotować, że w latach 1991-2000 zarówno Zakład Historii Wychowania, jak i Instytut Pedagogiki funkcjonował w strukturach Wydziału Humanistycznego. Z zachowanych w archiwum uniwersyteckim materiałów źródłowych wynika, że dekret Rady Ministrów z 24 sierpnia 1945 roku, zatwierdzony następnie przez Krajową Radę Narodową, powoływał do życia Uniwersytet Mikołaja Kopernika w formie dwuwydziałowej z Wydziałem Humanistycznym (wraz z Sekcją Sztuk Pięknych) i Matematyczno-Przyrodniczym. Ten historyczny akcent bytności humanistyki na UMK, począwszy od narodzin uczelni, uwypukla dodatkowy fakt, iż pierwsze wykłady inaugurujące działalność uniwersytetu zostały wygłoszone 24 listopada 1945 roku przez znakomitych humanistów ówczesnego Wydziału, profesorów Tadeusza Cieżowskiego i Stefana Srebrnego.

W roku akademickim 1999/2000, wieńczącym dziesięcioletni okres funkcjonowania Zakładu Historii Wychowania i Myśli Społecznej, Wydział Humanistyczny dysponował rozbudowaną strukturą organiza- 
cyjną. W jego skład poza Instytutem Pedagogiki wchodziły: Instytut Filozofii, Instytut Socjologii, Katedra Politologii, Katedra Psychologii, a także samodzielny Zakład Logiki i Semantyki. W ramach Instytutów i Katedr funkcjonowały samodzielne zakłady i pracownie. W strukturze organizacyjnej Wydziału funkcjonowało także Wyższe Zawodowe Studium Pedagogiczne (z wyodrębnionym, samodzielnym kierunkiem studiów) oraz Międzywydziałowe Indywidualne Studia Humanistyczne $-\mathrm{z}$ formą studiów o charakterze międzywydziałowym.

Władze dziekańskie Wydziału Humanistycznego tworzyli: dziekan - prof. dr hab. Ryszard Borowicz ${ }^{17}$, prodziekani: dr hab. Witold Wojdyło, dr hab. Ryszard Wiśniewski, prof. UMK; dyrektor Instytutu Filozofii - prof. dr hab. Włodzimierz Tyburski; dyrektor Instytutu Pedagogiki - prof. dr hab. Aleksander Nalaskowski; dyrektor Instytutu Socjologii - dr hab. Andrzej Zybertowicz, prof. UMK; kierownik Katedry Politologii - dr hab. Witold Wojdyło, prof. UMK; kierownik Katedry Psychologii - prof. dr hab. Augustyn Bańka; kierownik Zakładu Logiki i Semantyki - dr hab. Andrzej Pietruszczak, prof. UMK; kierownik Wyższego Zawodowego Studium Pedagogicznego - dr Jerzy Świątek; kierownik Międzywydziałowych Indywidualnych Studiów Humanistycznych - prof. dr hab. Mirosław Żelazny ${ }^{18}$.

17 Pracownicy nauki..., s. 107. Borowicz Ryszard Jerzy (1945-2014). Pracownik naukowy i dydaktyczny UMK w latach 1973-2014 m.in. w Katedrze i Instytucie Socjologii, w Instytucie Pedagogiki UMK, dziekan Wydziału Humanistycznego UMK w latach 1996-2002. Inspirator i organizator studiów politologicznych. Ryszard Borowicz był dwudziestym dziekanem Wydziału Humanistycznego. W latach 1945-1996 funkcję tę pełnili profesorowie: Konrad Górski, Kazimierz Hartleb, Bronisław Włodarski, Stanisław Hoszowski, Bronisław Nadolski, Jadwiga Lechicka, Leonid Żytkowicz, Kazimierz Żurowski, Wacław Cimochowski, Donald Steyer, Czesław Niedzielski, Leon Gumański, Antoni Czachorowski, Witold Wróblewski, Kazimierz Wajda, Stefan Cackowski, Andrzej Wojtas, Włodzimierz Wincławski, Lech Witkowski.

18 O Wydziale Humanistycznym UMK w latach 1945-2004 szerzej patrz: W. Wojdyło, Wydział Humanistyczny, w: Fides Quaerens Intellectum. Wiara poszukująca zrozumienia. Uniwersytet Mikołaja Kopernika w Toruniu w hołdzie Ojcu Świętemu Janowi Pawłowi II, pod red. ks. prof. dr. hab. J. Bagrowicza, Toruń 2004, s. 413-426. 


\section{Summary}

The Centre for Research on the History of Education in Toruń in the yeARs 1991-2000. Personal Reminiscences

This article is an ego-document that contains facts from the history of one of scientific and teaching units of Nicolaus Copernicus University. The information contained herein refers to both the history of the institution, i.e., Nicolaus Copernicus University, as well as the Department of History of Education and Social Thought, Pedagogy Institute, in 1991-2000. It describes the centre for scientific research and its traditions concerning the history of education. It also presents employees of the department, as well as the directions of research that has been conducted from 1945 to this day. 
